\title{
Ekspresi Caspase-3 pada Sel Epitel Rongga Mulut (Kb Cell Line) setelah Paparan Ekstrak Kopi
}

\author{
Suryani Hutomo*, Yanti Ivana Suryanto*, Heni Susilowati**, Agustinus Rudolf Phym*, dan Devi Chrestella Maheswara* \\ * Fakultas Kedokteran, Universitas Kristen Duta Wacana, Yogyakarta \\ ** Bagian Biologi Mulut, Fakultas Kedokteran Gigi, Universitas Gadjah Mada, Yogyakarta \\ * Gedung Agape lantai 5, JI. Dr. Wahidin 5-25 Yogyakarta 55224 suryanihutomo_drg@yahoo.com
}

\begin{abstract}
ABSTRAK
Kopi adalah minuman yang biasa dikonsumsi oleh masyarakat sehari-hari. Telah diketahui bahwa kopi mengandung kafein seperti yang terdapat juga pada teh dan coklat. Kandungan terbanyak kafein terdapat pada kopi. Kafein mempunyai struktur kimia 1, 3, 7-trimethylxanthine dan merupakan derivat xanthine. Senyawa ini dapat menginduksi kematian sel yang mengarah pada apoptosis, namun mekanisme yang terlibat belum diketahui dengan jelas. Tingginya konsumsi kopi di dunia yang selalu meningkat mengindikasikan perlunya dilakukan penelitian untuk mengetahui efek kafein pada epitel rongga mulut yang berkontak langsung dengan kafein. Penelitian terdahulu melaporkan bahwa ekstrak kopi menyebabkan kerusakan sel yang sebagian besar mengarah pada apoptosis, tetapi mekanismenya belum jelas. Tujuan penelitian ini adalah untuk menganalisis mekanisme kematian sel KB yang diinduksi oleh kafein melalui aktivasi caspase-3. Sel KB sebagai model epitel oral ( $\left.5 \times 10^{4} \mathrm{sel}\right)$ dikultur dalam DMEM menggunakan 24 wells microplate selama 24 jam sebelum perlakuan. Sel selanjutnya dipapar dengan kafein dengan konsentrasi $100 \mu \mathrm{g} / \mathrm{ml}, 200 \mu \mathrm{g} /$ $\mathrm{ml}, 400 \mu \mathrm{g} / \mathrm{ml}$ dan diinkubasi selama 24 dan 48 jam dalam DMEM. Doxorubicin $(0,5625 \mu \mathrm{g} / \mathrm{ml})$ digunakan sebagai kontrol positif induksi apoptosis. Teknik imunositokimia terhadap caspase-3 dilakukan pada sel setelah dipapar kafein untuk mengamati adanya ekspresi caspase-3 sebagai ciri apoptosis. Identifikasi caspase-3 dilakukan menggunakan mikroskop fase kontras. Ekspresi protein caspase-3 terdeteksi pada sitoplasma sel KB. Hasil penelitian ini menunjukkan adanya ekspresi caspase-3 aktif yang ditandai dengan warna cokelat dengan intensitas kuat pada sitoplasma sebagian besar sel setelah dipapar kafein dengan konsentrasi $100 \mu \mathrm{g} / \mathrm{ml}$ dan $200 \mu \mathrm{g} / \mathrm{ml}$ selama 24 jam. Disimpulkan bahwa ekstrak kopi menyebabkan apoptosis sel KB melalui jalur aktivasi caspase-3.
\end{abstract}

Maj Ked Gi. Desember 2014; 21(2): 122 - 126

Kata kunci: kopi, kafein, sel KB, apoptosis, caspase-3

\begin{abstract}
The Expression of Caspase-3 in Oral Cavity (Kb Cell Line) after Exposure to Coffee Extract. People widely consume coffee in daily meals. It is known there is caffeine found in coffee like it is found in tea and chocolate. Caffeine is found in the greatest amount of coffee. This 1, 3, 7- trimethyl xanthine substance is a derivate of xanthine that is consumed by almost all people in the world. This substance could induce cell death that mainly is apoptosis, but how the mechanism has not been clearly understood. Considering that coffee is widely consumed in the whole world, it is necessary to conduct an experiment to find any possible effect of caffeine to oral epitel that make direct exposure to caffeine. This experiment is targeted to analyze the mechanism of cell death which caused by caffeine through activation of caspase-3. KB cells as oral epithelial model (5x10 sel) were cultured in DMEM using 24 well microplate for 24 hours before treatment. Then caffeine was given with concentration of $100 \mu \mathrm{g} / \mathrm{ml}, 200 \mu \mathrm{g} / \mathrm{ml}$ and $400 \mu \mathrm{g} / \mathrm{ml}$. Cells were then incubated for 24 and 48 hours period in DMEM. Doxorubicin $(0,5625 \mu \mathrm{g} / \mathrm{ml})$ was used as a positive control of apoptosis induction. Immunocytochemistry technique was then done to observe any caspase three expression as a marker for apoptosis. Identification of active caspase-3 was then done using contrast phase microscope. The results showed expression of caspase-3 in KB cells cytoplasm which observed as high intensity of brown colored molecules in cell cytoplasm after $100 \mu \mathrm{g} / \mathrm{ml}$ and $200 \mu \mathrm{g} / \mathrm{ml}$ caffeine exposure in 24 hours. It was concluded that coffee extract induce $K B$ cells apoptosis through caspase- 3 activation mechanism.
\end{abstract}

Maj Ked Gi. Desember 2014; 21(2): 122 - 126

Keywords: coffee, caffeine, KB cells, apoptosis, caspase-3

\section{PENDAHULUAN}

Kopi adalah minuman yang biasa dikonsumsi oleh masyarakat sehari-hari. Kopi mengandung kafein dalam jumlah yang cukup besar. Selain terkandung dalam kopi, kafein terkandung pula dalam teh dan coklat. Kafein mempunyai struktur kimia 1, 3, 7- trimethylxanthine, merupakan derivat xanthine dan dikonsumsi oleh masyarakat di seluruh dunia. 
Kandungan terbanyak kafein terdapat pada kopi, yaitu sebesar 40-180 mg/cangkir. ${ }^{1}$ Konsumsi kafein di dunia mencapai 1-2 mg/kg/hari. Konsumsi tersebut setara dengan $70-140 \mathrm{mg}$ kafein pada individu dengan berat badan $70 \mathrm{~kg} .{ }^{2}$ Menurut Badan Pengawas Obat dan Makanan (BPOM), konsumsi kafein maksimum adalah sebesar $150 \mathrm{mg} / \mathrm{hari}$. Sementara itu kandungan kafein dalam minuman adalah sebesar $50 \mathrm{mg}$ per saji.

Kafein dapat menstimulasi otak dan mempengaruhi mood $^{2}$, meningkatkan kemampuan berpikir, ${ }^{3}$ menunda onset tidur, ${ }^{4}$ meningkatkan aliran pembuluh darah koroner, produksi urin, sekresi lambung, dan metabolisme basal. ${ }^{5}$ Konsumsi kafein juga dapat menurunkan faktor resiko penyakit Parkinson, ${ }^{6}$ menurunkan densitas mineral tulang femur pada pria usia lanjut, serta menyebabkan ${ }^{7}$ intrauterine growth retardation (IUGR) dan berat badan lahir rendah pada bayi. ${ }^{8}$ Penelitian-penelitian terdahulu melaporkan bahwa kafein bersifat toksik terhadap sel. Kafein pada konsentrasi setara dengan $10 \mathrm{mM}$ memiliki efek toksik terhadap sel neuroblastoma manusia SK-N-MC dan toksisitasnya akan semakin meningkat sebanding dengan lama waktu paparan terhadap sel. ${ }^{9}$ Paparan kafein terhadap osteoblas menunjukkan adanya apoptosis sehingga konsumsi kafein dapat menjadi faktor resiko terhadap osteoporosis. ${ }^{10}$ Penelitian yang dilakukan oleh Phyma dkk. (2014, naskah dalam preparasi) melaporkan bahwa viabilitas sel KB mengalami penurunan karena adanya paparan ekstrak kopi, sementara prosentase kematian sel KB juga meningkat sebanding dengan besarnya konsentrasi kafein. Sementara itu penelitian yang dilakukan oleh Maheswara dkk. (2014, naskah dalam preparasi) melaporkan kematian sel KB yang dipapar ekstrak kopi sebagian besar didominasi oleh apoptosis, namun mekanisme yang terjadi belum jelas.

Epitel oral merupakan bagian dari tubuh yang pertama kali akan terpapar langsung oleh minuman kopi, sehingga perlu diwaspadai dosis kafein yang terkandung dalam kopi yang dapat ditoleransi olehnya. Mengingat tingginya konsumsi kopi di dunia perlu dilakukan penelitian untuk mengetahui efek kafein pada epitel rongga mulut yang berkontak langsung dengan memahami mekanisme kerusakan sel yang disebabkannya. Pada penelitian ini digunakan KB cell line sebagai model epitel oral. Meskipun berbeda dengan epitel oral normal, beberapa penelitian melaporkan bahwa reaksi dan akibat dari perlakuan terhadap kedua epitel itu memberikan hasil yang sama. 11,12

Di antara 14 caspase yang ada, caspase-3 merupakan major executioner gen pada apoptosis yang dipicu oleh berbagai stimulus ${ }^{13} \mathrm{Hal}$ ini mendasari kajian mekanisme apoptosis berdasarkan ekspresi caspase-3 pada penelitian ini. Penelitian ini telah mendapatkan persetujuan etik dari Komisi Etik Fakultas Kedokteran Universitas Kristen Duta Wacana Yogyakarta.

\section{METODE PENELITIAN}

Pembuatan ekstrak kafein. Ekstrak kafein berasal dari biji Coffee arabica dari Temanggung, Jawa Tengah, Indonesia. Biji kopi dicuci bersih kemudian dikeringkan di bawah sinar matahari. Setelah itu, biji kopi tersebut disangrai, kemudian dijadikan serbuk dengan menggunakan mesin penggiling. Pembuatan ekstrak dilakukan dengan cara maserasi, yaitu merendam serbuk kopi di dalam etanol $70 \%$ selama 24 jam. Ampas selanjutnya diperas dan diteruskan dengan penyaringan. Ampas ditambah dengan cairan penyari yaitu etanol $70 \%$ dan dilakukan kembali perendaman selama 24 jam. Ekstraksi tersebut dilakukan 3×24 jam. Larutan yang dihasilkan ditampung dan selanjutnya sisa-sisa larutan ekstraksi diuapkan dengan rotatory evaporator.

Kultur sel KB (KB cell line). Pada penelitian ini digunakan sel KB sebagai model epitel oral. Sel KB merupakan koleksi dari Laboratorium Penelitian dan Pengembangan Terpadu, Universitas Gadjah Mada, Yogyakarta. Sel dikultur dalam medium DMEM dengan suplemen 10\% FBS, penisilinstreptomisin, dan fungizone. Kultur yang telah mencapai tingkat kepadatan $80 \%$ dipanen untuk selanjutnya dikultur kembali dalam DMEM pada 24 wells microplate sebagai subjek perlakuan yang akan dipapar dengan kafein, sel KB diinkubasi semalam pada suhu $37^{\circ} \mathrm{C}$ dalam inkubator dengan tekanan $\mathrm{CO}_{2} 5 \%$ sebelum diberi perlakuan. 

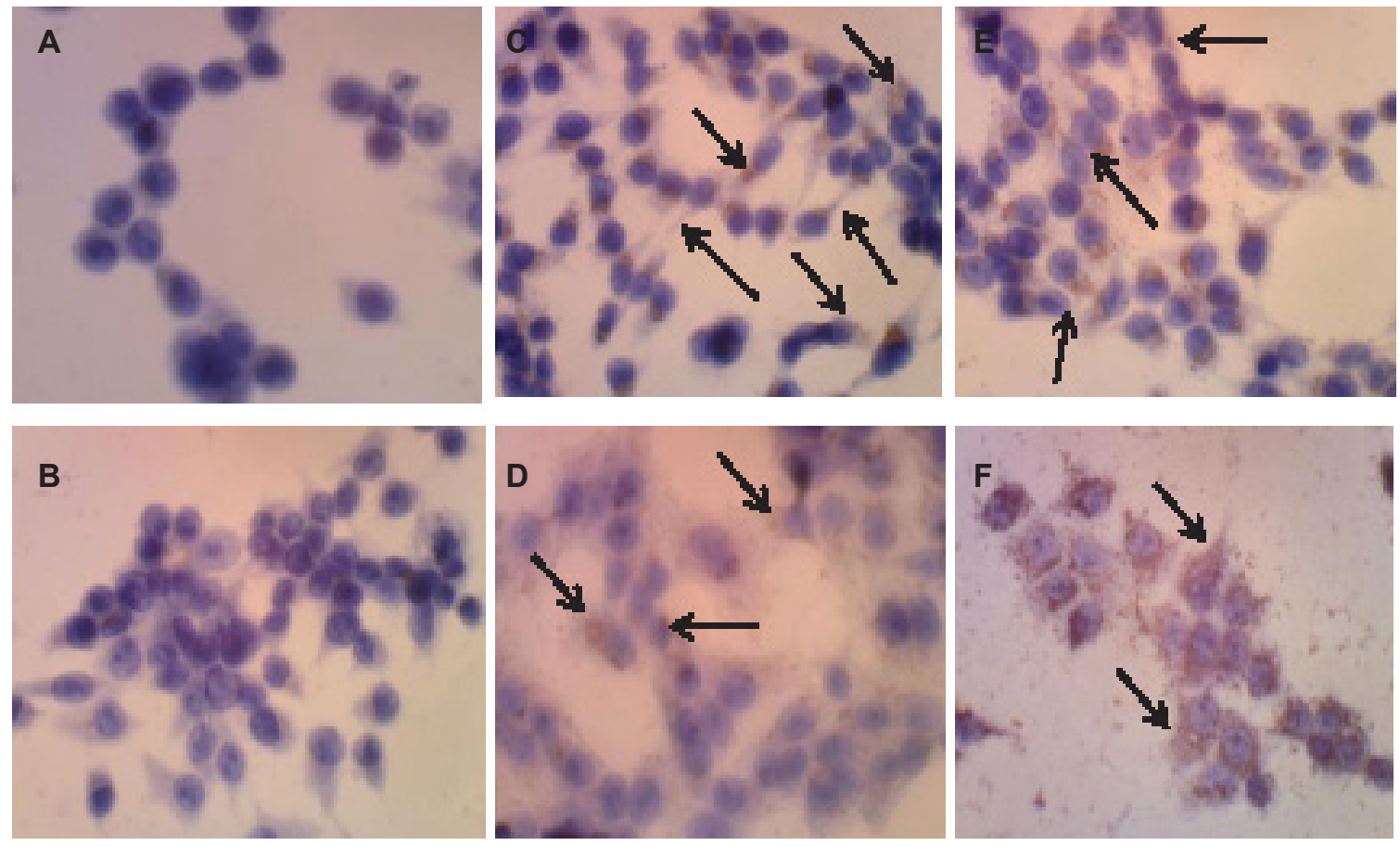

Gambar.1. Sel KB tanpa paparan kafein (A, B). Ekspresi caspase-3 tampak jelas pada paparan $100 \quad \mu \mathrm{g} / \mathrm{ml}$ selama 24 dan 48 jam (C, D), $200 \mu \mathrm{g} / \mathrm{m}(\mathrm{E}, \mathrm{F})$.

Analisis ekspresi caspase 3 sel KB. Sel KB dikultur pada microplate 24 well dengan coverslip pada tingkat kepadatan $5 \times 10^{4} \mathrm{sel} /$ well. Setelah 24 jam kultur, sel dipapar dengan kafein pada konsentrasi $100 \mu \mathrm{g} / \mathrm{ml}, 200 \mu \mathrm{g} / \mathrm{m}$ dan, $400 \mu \mathrm{g} /$ $\mathrm{ml}$ selama 24 jam dan 48 jam. Sebagai kontrol negatif, sel KB dikultur dalam DMEM tanpa kafein, sedangkan sebagai kontrol positif, sel KB dikultur dalam DMEM dan dipapar dengan Doxorubisin (Kalbe Farma Indonesia) dengan konsentrasi $0,5625 \mu \mathrm{g} / \mathrm{ml}$. Pengecatan imunositokimia menggunakan anti-active caspase 3 (Rabbit Monoclonal Antibody, Abcam, Cambrige, UK) pada coverslip yang diletakkan pada glasslide untuk deteksi aktivasi caspase.

Pengamatan ekspresi caspase-3 pada sel KB setelah paparan kafein dilakukan menggunakan mikroskop fasekontras. Ekspresi caspase-3 diamati pada sitoplasma.

\section{HASIL PENELITIAN}

Hasil penelitian menunjukkan bahwa protein caspase-3 terekspresi dengan sangat jelas pada sitoplasma sel KB setelah paparan ekstrak kopi dengan konsentrasi $100 \mu \mathrm{g} / \mathrm{ml}$ dan $200 \mu \mathrm{g} / \mathrm{ml}$ selama 24 jam, sedangkan pada 48 jam terekspresi jelas pada konsentrasi $100 \mu \mathrm{g} / \mathrm{ml}$. Hasil disajikan pada Gambar 1 dan 2

Pada paparan ekstrak kopi konsentrasi 400 $\mu \mathrm{g} / \mathrm{ml}$ selama 24 jam, masih tampak adanya ekspresi caspase-3 pada sebagian kecil sitoplasma sel, sementara pada konsentrasi yang sama dengan paparan selama 48 jam sebagian besar sel telah mengalami kerusakan. Adanya ekspresi caspase-3 aktif pada sel KB yang dipapar ekstrak kopi mengindikasikan proses kematian sel KB merupakan proses apoptosis melalui jalur aktivasi caspase-3.

\section{PEMBAHASAN}

Hasil penelitian ini menunjukkan adanya ekspresi caspase-3 pada sitoplasma sel KB yang dipapar ekstrak kopi. Fenomena yang terjadi pada penelitian ini sejalan dengan penelitian terdahulu, yaitu kafein pada konsentrasi setara dengan $10 \mathrm{mM}$ memiliki efek sitotoksik terhadap sel neuroblastoma 

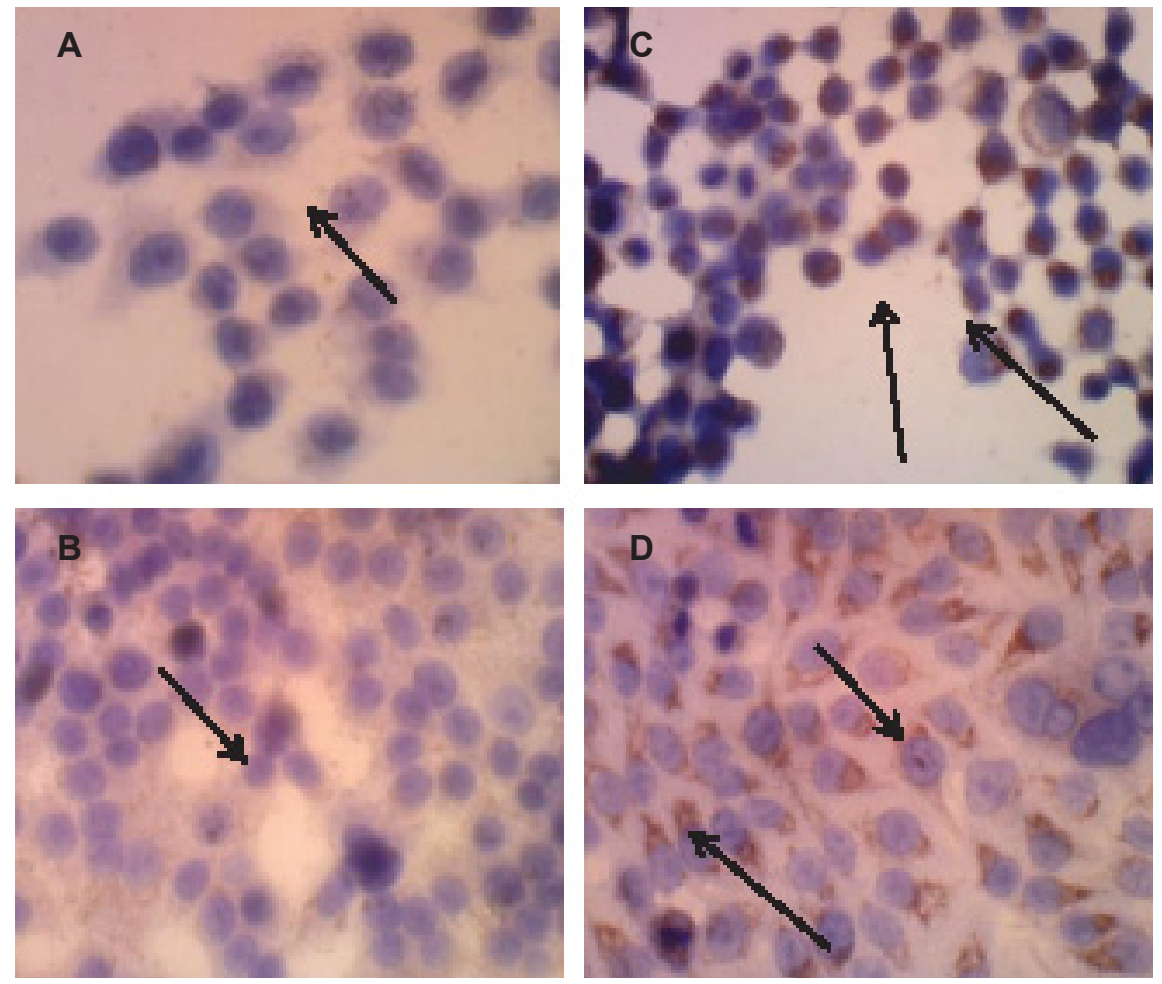

Gambar 2. Sel KB dengan paparan ekstrak kopi $400 \mu \mathrm{g} / \mathrm{ml}(\mathrm{A}, \mathrm{B})$. Ekspresi caspase-3 pada sel $K B$ yg dipapar doxorubicin $(C, D)$.

manusia SK-N-MC dan efek tersebut akan semakin meningkat sebanding dengan waktu paparan kafein terhadap sel. Dilaporkan pula bahwa konsentrasi kafein yang tinggi dapat menyebabkan apoptosis melalui peningkatan aktivitas enzim caspase $3 .{ }^{9}$

Induksi dan eksekusi apoptosis melibatkan suatu sistem yang meliputi enzim, gen pengatur dan reseptor. Diantara sistem tersebut terdapat caspase yang terbagi dalam 2 grup, yaitu caspase inisiator (caspase-2, 8, 9, 10) dan caspase eksekutor (caspase-3, 6, 7). Diantara 14 caspase yang ada, caspase-3 merupakan faktor kunci dari eksekusi apoptosis. Caspase-3 dapat masuk ke nukleus melalui pori-pori yang dibuat oleh caspase-9, mengeluarkan substrat yang menyebabkan degradasi DNA. Lamin A dan fodrin merupakan komponen skeleton nukleus dan skeleton sitosolik. Pemecahan lamin oleh caspase-3 akan menyebabkan kondensasi kromatin, sementara pemecahan fodrin memicu pembentukan apoptotic bodies. $^{13}$
Ada 2 jalur terjadinya apoptosis yang melibatkan caspase, yaitu jalur ekstrinsik yang terjadi bila sinyal apoptosis yang diterima death receptor cukup kuat. Bila sinyal tidak cukup kuat, maka akan dipancarkan ke mitochondria, terjadi pelepasan cythochrome-c yang kemudian akan mengaktifkan caspase-3 untuk mengeksekusi apoptosis. Jalur yang kedua ini dinamakan jalur intrinsic ${ }^{14}$ Pada penelitian ini didapatkan ekspresi caspase-3 pada sitoplasma sel cukup kuat yang ditandai dengan warna coklat yang jelas pada sitoplasma sel, sehingga kemungkinan besar proses apoptosis yang terjadi pada sel KB yang diinduksi ekstrak kopi ini melalui jalur ekstrinsik. Hasil dari penelitian ini menunjukkan bahwa ekstrak kopi yang mengandung kafein cukup tinggi dapat menyebabkan apoptosis sel KB melalui mekanisme aktivasi caspase-3, sehingga perlu diwaspadai dosis kafein yang boleh dikonsumsi oleh seseorang agar tidak merusak epitel mukosa mulut. Pada penelitian ini tidak dilakukan identifikasi jenis- 
jenis zat yang terkandung pada ekstrak kopi satu persatu, sehingga perlu dilakukan penelitian lebih lanjut untuk mengidentifikasinya dan memastikan kandungan zat penyebab apoptosisnya.

\section{KESIMPULAN}

Ekstrak kopi menyebabkan apoptosis sel KB melalui mekanisme aktivasi caspase-3.

\section{DAFTAR PUSTAKA}

1. Chou,T. Wake up and smell the coffeecaffeine, coffee, and the medical consequences. The Western Journal of Medicine. 1992; 157: 544-553.

2. Nehlig A. Dependence upon coffee and caffeine: an update. Dalam: Nehlig A. ed. Coffee, tea, chocolate, and the brain. Florida : CRC press; 2004. h. 138.

3. Fredholm BB, Battig K, Holmen J, Nehlig A, Zuartav E. Actions of caffeine in the brain with special reference to factors that contribute to its widespread use. Pharmacological reviews. 1999; 51: 83-133.

4. Snel J, Tieges Z, Lorist MM. Effects of caffeine on sleep and wakefulness: an update, dalam: Nehlig A. ed. Coffee, tea, chocolate, and the brain. Florida : CRC press; 2004. h.22.

5. Louisa M, Dewoto HR. Perangsang susunan saraf pusat, dalam Gunawan SG,Setiabudy R, Nafrialdi, Elysabteh. Farmakologi dan terapi edisi 5. Jakarta: Departemen Farmakologi dan Terapeutik Fakultas Kedokteran Universitas Indonesia; 2007.

6. Liu R, Guo X, Park Y, Huang X, Sinha R, Freedman ND, Hollenbeck, AR. Caffeine intake, smoking and risk of parkinson disease in men and women. American Journal of epidemiology. 2012; 175 (11): 1200-1207.

7. Hallström $H$, Melhus $H$, Glynn A, Lind L, Sylvanen AC, Micahelsson K. Coffee consumption and CYP1A2 genotype in relation to bone mineral density of the proximal femur in elderly men and women: a cohort study. Nutrition and metabolism. 2010; 7:12.

8. Bracken MB, Triche EW, Belanger $\mathrm{K}$, Hellenbrand K, Leaderer BP. Ascociation of maternal caffeine consumption with decrements in fetal growth. American Journal of Epidemiology. 2002; 5(15): 456-466

9. Jang $\mathrm{MH}$, Shin MC, Kang IS, Baik $\mathrm{HH}$, Cho $\mathrm{YH}, \mathrm{Chu}$ JP, Kim EH, Kim CJ. Caffeine induces apoptosis di human neuroblastoma cell line SK-N-MC. Jounal of The Korean Academy of Medical Sciences. 2002; 17: 674-8.

10. Tsuang HY, Sun JS, Chen LT, Sun SCK, Chen SC. Direct effects of caffeine on osteoblastic cells metabolism: the possible causal effect of caffeine on the formation of osteoporosis. Journal of Orthopaedic Surgery and Research. 2006; Oct 7:1-7

11. Huang FM, Tai KW, Hu CC, Chang YC. Cytotoxic effects of denture base materials on a permanent human oral epithelial cell line and on primary human oral fibroblast in vitro. The international journal of prosthodontics.2001; 14 (5): 439-443.

12. Lourbakos A, Potempa J, Travis J, D'Andrea MR, Gordon P.A., Santolli, R., Arginine specific protease from Porphyromonas gingivalis activates protease-activated receptors on human oral epithelial cells and induces interleukin-6-secretion. Infection and immunity. 2001; 69 (8): 5121-5130

13. Fan TJ, Han LH, Cong RS, Liang J. Caspase family proteases and apoptosis. Acta Biochimica et Biophysica Sinica. 2005; 37(11): 719-727.

14. Elmore, S. (2007) Apoptosis: A Review of Programmed Cell Death: Toxicologic Pathology, (35): 495-516 